\title{
THE ROLE OF THE SUPREME COURT IN PRIVATE LAW CASES
}

\author{
ALBERT S. ABEL *
}

Now that the functions appropriate to the central and the member governments of the country are being fundamentally re-examined, critical scrutiny, rather than the traditional unthinking acceptance of the Supreme Court's role as monitor of the private law, is in order. That discussion has centered on the political branches to the virtual exclusion of the judiciary is understandable. It has come about primarily because of the greater public awareness of, and consequent sensitivity to, what legislators do as against what judges do; but also, in part, because the classic confusion of the familiar with the necessary has insulated the Court from query, let alone inquiry, as to whether what they have been and are doing is what they ought to be doing in the context of a federal system. It is my thesis that it is not; and that, outside of the federal fields, the law of the several provinces ought to be left for the provinces to determine judicially, as it is legislatively. A suggestion so out of line with routine notions will, of course, not win ready adherence. But one can hope that the Canadian bar and public are open-minded enough not to dismiss it out of hand because it is unorthodox. Let it be doubted, but let it be examined.

In the United States, the matter has been worked out within the framework of Article III, section 2, of the Constitution, the terms of which influenced-nowadays probably no provisions of that instrument do more than that and many do less - the determination of what law is for the federal courts, including the United States Supreme Court, authoritatively to decide and what for the state courts. Structurally, all its text does is to list the kinds of suits which the federal courts may entertain, saying nothing about the techniques of decision, in contrast with the "supremacy clause" of Article VI which commands all courts, specifically including state courts, to follow any relevant federal law. Broadly, the scheme of Article III, section 2, restricts federal judicial competence to particular issues-the "federal questions jurisdiction"-or alternatively according to the character of the parties, of which by all odds the commonest case in practice is diversity of citizenship-"Controversies . . . between citizens of different States." In silent recognition of the principle, expressio unius exclusio alterius, it has always been understood that no claim grounded purely on state statutory law or common (in Louisiana, civil) law between citizens of a single state ${ }^{1}$ is receivable by a federal court either at first instance for by way of review. There one draws a total blank, which does not go far to clarify the respective roles of the federal and the state courts in settling the content of the law even with any inferences permissible from the silences. The matter has been made explicit, however, in cases where the law involved is a state statutory or common law rule but the case is maintainable in the federal courts because of the character of

- Albert S. Abel, Professor of Law, University of Toronto, Toronto.

1 The statement, while too broad in omitting (a) other exceptional categories of parties, (b) the possibility of challenging a state statutory or common law rule as invalid under the United States Constitution or as overridden by a federal law, is accurate enough to Bive the Beneral picture. 
the parties. It is in this context that the case of Erie Railroad Company v. Tompkins, ${ }^{2}$ supplanting that of Swift v. Tyson, ${ }^{3}$ has established that, for substantive as contrasted with procedural law, the federal courts are bound by state court pronouncements exactly as state courts always were bound by federal decisions respecting the content of federal law.

To trace the consequences and ramifications of the rule as to the identification of authoritative current law, the classification as substantive or procedural, the extension of the policy to state law ingredients incident to the federal question jurisdiction, to mention only some of the more interesting problems, would serve no present purpose; but it may perhaps be noted that, even under Swift v. Tyson, questions other than those of "general or commercial law" and, specifically, questions turning on a state statute had always been for state court decision. This did not mean, and the rule of Erie v. Tompkins does not now mean, that federal courts were ousted from consideration of cases involving state law or vice versa; ${ }^{4}$ but that, as where in a conflict-of-laws situation, law not of the forum is to be applied, or, again, as where chancery undertook to "follow the law," they do not decide independently what that law is, but conform to the views on that of another set of judges." What results is a judicial hegemony of the states analogous to the division of legislative authority between them and the United States.

That, which is substantially what I am here urging, involves as its first and plainest corollary that the Supreme Court refrain from reviewing any case which falls within the range of matters of provincial concern-which by and large means one with respect to property and civil rights.

It is true that one of the significant ways in which the Canadian constitution differs from that of the United States is that, here, only legislative powers are allocated in so many words between the Dominion and the Provinces, in contrast with the extension, there, of the federal principle to all branches of government. In the parliamentary scheme which we have, the intimate linkage of the legislatures and the executive somewhat obscures the situation as to the latter, while limiting to the residues of prerogative any meaningful problems of federal and provincial competence. What here concerns us is that the separation of powers concept does obtain for the judicial branch in Canada, as indeed in Britain; and that, as to that branch, a distribution of authority between the provinces and the Dominion is neither expressed nor, because of separation of powers, can be said to carry over from the places where it is specified in the British North America Act. These are, notably, sections 91, declaring the matters which "the exclusive Legislative Authority of the Parliament of Canada extends to," and 92, listing those as to which "(i)n each Province the Legislature may exclusively make laws," supplemented by others such as sections $93,94 a$, and 95 , as to which, with various qualfications, either the Parliament of Canada or the Legislature in each Province may "make Laws."

2 (1938), 304 U.S. 64, 58 S.Ct. 617, 82 L.ed. 1188.

3 (1842), 16 Pet. 1, 10 L.ed. 865.

4 See, e.8., Testa v. Katt (1947), 330 U.S. 386, 67 S.Ct. 810, 91 L.ed. 967.

5 The United States Supreme Court will not review Court of Appeals decisions which involve only applications of state law, though it will require that that law be applied. 
The structure of the Act, thus, clearly rebuts any suggestion that it commands for decisional law a recognition of areas of provincial and of federal competence respectively analogous to those it sets out for statute law. That does not amount to saying it forbids it. It does not even amount to saying that the Act contemplates a single authoritative propounder of judicially developed law for the whole country, although an assumption that it does is by now part of the mental set of Canadian lawyers and political scientists-so much so that this invitation to look just at the Act, unblinkered by pre-conceptions, may, I fear, be rejected by many as heretical.

It is easy to see how people slipped into that rut. Indeed, it is almost inevitable that they should. Two things conduced to do it, the one broadly jurisprudential, the other institutional and special to the British Empire as it stood in the late 19th and early 20 th century.

First, leaving aside for the moment the civil law orientation of Quebec, it has always been understood that, as to the other provinces, their legal system is the common law system. But what does that mean? The "common law" has received variant meanings in special contexts, as in contrasting the common law and equity or the law merchant or in distinguishing common law from legislation, thus amply demonstrating that the phrase is not one with fixed contours, but has various senses. It is doubtful how far this was appreciated, or is even now appreciated, in the selection of the appropriate one for talking about the prevalence of the common law in Canada.

What was at issue? On the one hand, the common law designates one member of the family of the world's great legal systems, among whose fellows are Roman law and its offshoot the modern civil law, Islamic law, Scandinavian law, the law of the Torah, and Chinese law. This, which is what the comparative lawyers would have in mind, regards "the common law" as one of the great and distinctive aggregates of procedures, postulates, and principles serving for the orderly classification and analysis of legal systems. It is in this sense that the United States and Eire are countries of the common law as truly as is any member of the British Commonwealth of Nations. At the opposite pole, "the common law" bears the significance of the domestic non-statutory rules judicially enforced from time to time in England and Wales in all their particularities of application, qualification, and modification. An English lawyer advising a client about his common law rights in England would have in mind this local and transitory set of judicial determinations-ready enough, withal, to accept as proper common law the English case law of 1300, 1700 , and 1850 of quite different content, although skeptical, perhaps, whether American or, for that matter, Canadian or Australian deviations are such.

As between these two meanings, the more expanded formula, at times expressed, otherwise always understood, that it is the "common law of England" which is the relevant basis, gives no guide. Both have that in mind. The difference is that the one looks to English principles, the other to current English practices.

The unsophisticated Austinianism of the bench and bar that prevailed at the time our Canadian judicial system was getting under way-and that 
has not yet vanished-was congenial to the narrower approach. It led to a taking for granted, without examination and, indeed, without consideration, of the view of the common law as a corpus of detailed prescriptions -what else could the sovereign" command?-which must be everywhere identical. That conception of the common law necessarily presupposed a single authoritative expounder. This cookbook theory of the common law, under which there was only one right way of making muffins and where to learn whether a lump of butter was the size of a walnut one always had to find out from grandma what walmut she had in mind, has now a quaint unreality (not charm); but in its time, which happened to be the formative era of Canadian statehood, it was widespread, and gave a bias to Canadian professional thinking from which it has not yet rid itself. This is the broadly jurisprudential element mentioned as explaining the fallacious conclusion that the British North America Act not only failed to prescribe but actually proscribed judicial federalism.

That view was re-enforced by what was then the role of the Judicial Committee of the Privy Council. It monitored the courts of the whole Empire other than those of the mother country (to use the terminology then current). One took to it for ultimate resolution questions of the content of the law of every one of that magnificent array of colonies, dependencies, and possessions-not just common law, but civil law and native customary law, too, where those were the systems. No doubt Imperial Acts and its own traditions limited the appeal it would entertain, but nothing limited its mission of setting the local courts right as to the law in their several localities when it did take a case. This institutionalization of the notion of a homogenized law or, at any rate, of a uniquely qualified law interpreter for the whole Empire pretty well ruled out inquiry as to autonomous legal development in the several members. If even Canada's or, later, Australia's highest courts could not determine their own law, how then should those of places like New Brunswick or Queensland? Since 1949, we are going to recognize that Canadian judges can appropriately determine Canadian law; but the old indoctrination persists when it become a question of whether Alberta judges can appropriately determine Alberta law.

The climate of opinion, aggravated by the general human weakness for the negative pregnant, made it almost inevitable, then, that the failure to specify a judicial division between the provinces and the Dominion should be read as a direction that there be no such division; but there are scattered indications to the contrary in the very text of the British North America Act. It would be going too far to say that the Fathers of Confederation expressed their views clearly on the point. Indeed, it seems likely that they did not entertain any clear views. Still, what they did say manifests a recognition on their part that the law varied among the provinces and an acceptance of that difference as a continuing phenomenon.

There are at least two indications to that effect.

One is that, unlike the United States Constitution, which had decreed that "the judicial power of the United States shall be vested in one supreme Court, and in such inferior Courts as the Congress may from

B The writer is quite aware that the Cheshire Cat "sovereignty" of the American states never under any theory characterized the Canadian provinces. 
time to time ordain and establish," our constitution enacted only that "the Parliament of Canada may . . . provide for . . . a General Court of Appeal for Canada, and for the Establishment of any additional Courts for the better Administration of the Laws of Canada." If "for the better Administration of the Laws of Canada" modifies "General Court of Appeal" as well as "additional Courts," it is arguable that the words limit potential judicial competence to matters of federal law. Not only is "the laws of Canada" a phrase which the Act uses nowhere else, but the Act speaks several times distinctly of "Laws" of the Provinces and the "Laws" of the federal Parliament. However, the section as it now appears seems to be a consolidation of two provisions in Sir John A. Macdonald's draft address to Her Majesty for the Union of the British North American Provincesone in what eventually became section 91 , listing among the powers of Parliament "The establishment of a General Court of Appeal for the Federated Provinces," and the other in a separate section, to the effect that "the General Parliament may also, from time to time establish additional courts .... . in order to the due execution of the laws of Parliament."s It would seem, then, that the expression modifies only the words which it immediately follows; and that, while Parliament in setting up courts other than the Supreme Court is indeed restricted to giving them jurisdiction only over federal law, that is not true for the "General Court of Appeal." What is significant, however, is that, in making the Supreme Court's existence permissive instead of, as the Americans had done, mandatory, the Act seems clearly to have envisaged the indefinite continuance of a state of affairs where the law might be diversely ruled by the Courts of the provinces with no federal supervision of their rulings. This no doubt was in a setting where an appeal to the Privy Council was always possible and, thus, provincial law was subject to outside control-but, be it noted, an outside control not on the basis of a law common to Canada but on an Empire-wide application of English holdings. In fact, Parliament seems to have felt there was no special urgency about altering the situation where the courts of each province decided its laws with no common superior in Canada, for the Supreme Court was not established until 1875, eight years after Confederation (in sharp contrast with the United States, where the first order of business 1 " had been the erection of the Supreme Court and the circuit courts). In the interval from 1867 to 1875 , the matter, thus, rested perforce on provincial determination. ${ }^{11}$

Even more strongly than the Fathers' tolerance of the pre-existing state of affairs, which is to be implied from letting Canada go along without a Court, section 97 premises a diversity in the laws of the provinces. Under it, the judges in their courts are to be selected from their several bars, "[u]ntil the Laws relative to Property and Civil Rights in ... [the common law provinces entering into Confederation] are made uniform." There could hardly be a clearer recognition that the laws with respect to

7 Italles supplled.

8 See Parliamentary Debates on Confederation 1029.

o C.. Consolidated Distilleries v. The King, [1933] A.C. 508, [1933] 3 D.L.R. 1.

10 The Judiciary Act of 1789 , which created the Supreme Court, derived from Senate Bill No. 1 of the First Congress.

11 The provincial courts seem to have had quite a free rein, in fact, in pronouncing the content of the common law. The Law Reports set out from I July, 1867, through 1875 a total of 41 judgments in cases coming from Canada. Of this total, 34 were Quebec cases, leaving only 7 for all the other provinces and evidencing a readiness of the Privy Council to rule on the civil law while leaving the common law to the provincial courts. 
the matters spoken of were not uniform at the time of writing; nor, indeed, a much clearer manifestation that, whatever might be hoped, they were not expected to be so right away. But the non-uniformity recognized as existing and as likely to continue involved, almost certainly, a non-uniformity of common law. Quebec had its Code; but in the named provinces, New Brunswick, Nova Scotia, and Ontario, property and civil rights were, to an even greater extent than now, ruled by judicially formulated rules instead of legislation, so that any lawyer adverting to differences would have contemplated primarily differences in common law doctrine. If it was evisaged that there was in existence potentially a single common law of Canada awaiting only an expounder, that potential uniformity would have been realized with the establishment of the Supreme Court. Yet, it is universally accepted that section 97 is a dormant clause of the constitution, and nothing but astonishment would greet the suggestion that its condition has been satisfied and that the judges in Onario may now be appointed from the bar of Nova Scotia. The principle underlying this limitation on recruitment of the judiciary seems, indeed, to be identical to that expressed by the United States Supreme Court for deferring to the federal district courts as to what state law is-i.e., that they are "composed ... wholly of citizens of the state familiar with ... the local conditions to which it applies and the character of the State's laws."12 But these considerations of familiarity with the legal and social context, if relevant to who should be eligible to be judges, would seem as relevant to what is the proper function of the courts which those judges constitute.

These two provisions, then-the permissive and procrastinating directive as to a federal judiciary and the recognition of persisting non-uniformity in the law as to property and civil rights in the common law provinces -predicate judicial self-determination in those provinces as an existing condition (not necessarily, of course, as an ideal or as a directive). Laskin's view that the doctrine of Erie v. Tompkins "has no place in Canadian constitutional law"13 is true to the extent that it denies a constitutional compulsion on the Supreme Court to accept the views of the provincial courts; but several of the concurring justices in Erie itself rejected the Brandeis thesis that a constitutional issue was presented. If Professor Laskin is proposing (which is not made too clear) that the recognition of provincial court finality as a principle of judicial action would contravene the spirit of the British North America Act, I must venture to disagree and to submit that, as revealed by the two provisions examined above, it rather supports than impugns such recognition. Though somewhat more congenial to such judicial autonomy, it is compatible with either approach. There is no constitutional mandate. It is wholly a question of what is the appropriate policy for the Supreme Court to adopt, and to the policy question the rest of this discussion addresses itself.

The issue has been obscured by the related, but special, campaign for a re-examination of the Court's role as interpreter of the Civil Code of Quebec. I have the fullest sympathy with Quebec's advocacy of fundamental changes in this connection, but I see that as simply the most conspicuous illustration of the more general problem. The various schemes

12 Thompson v. Consolidated Gas Utilities Corp. (1937), 300 U.S. 55, 75, per Brandeis, J. 13 Laskin, Canadian Constitutional Law, 806 (1960). 
which seek to solve in isolation Quebec's claims, be they by way of a bifurcated court, an explicit constitutional exemption for the Civil Code, or what not, seem to me misconceived. Let it be said that Quebec is not a province tout comme les autres. I quite agree-but with the addendum that none of them is. The life and people of New Brunswick do not duplicate those of Saskatchewan; Ontario and Newfoundland do not repeat each other. Each of the provinces has things in common with all of the others, things in common with some of the others, and things which are its own. The distinctive attributes are visibly, and probably substantially, most preponderant in Quebec. But it is a matter of degree. The terms of the dialogue have themselves been productive of obfuscation. The talk of French Canada and English Canada, of systems of civil law and of common law, gives a spurious monotony to the second member of each dichotomy. For immediate purposes, lumping together all the individuals in a class may be a convenient shorthand; but it falsifies the individuality which, on another level, is significant. In reverse Orwellese, though some are more unequal than others, still all are unequal. The solid foundation of Quebec's position is that all should be maitres chez soi, within the limits of the agreed fabric of common national purpose as revised from time to time. The virtue of a federal, as contrasted with a centralized, structure is the scope it gives for the members to fulfill their several personalities and to respond to their special needs according to their special values; and the strength of Quebec's case is, at bottom, the strength of the federal principle. Granted that her personality, values, and institutions are the most unambiguously distinctive, the less marked differences between the other provinces should neither be overlooked nor repressed. Formulae confined to Quebec's position do not go to the heart of the matter. What is fundamentally involved are the merits of provincial self-determination. Quebec self-determination does not change the nature of the issues. It only brings them into sharper focus. Once freed from a misapprehension about the common law found in the other provinces, that it is a corpus of uniform prescriptions, and brought to see it as simply a legal system of variable content, Quebec will not, I am sure, wish to deny to them the power of autonomous legal development she legitimately claims for herself.

Nor should the policy issue be distorted by any suggestion that the qualifications of the Supreme Court are somehow being challenged. They are not. On and for the record, I believe that the general level of ability and performance of its judges has been over the years superior to that of any other court in Canada, as indeed seems natural, given its status and the consequent range of recruitment to membership. I do not anticipate that its withdrawal from the field would produce an academically prettier course of decision. The law as a logical construct might very probably suffer. But that aspect of the law, though not unimportant, is much less important than is its functional aspect as an instrument of social accommodation, and any loss as to the former would be greatly outweighed by the greater familiarity of local judges with the relevant social context.

Always, where autonomy confronts control, the choice at its starkest becomes that between the competing values of self government and of better government; and so here. Most of us compromise by asking for a 
little of both, please; and so here. But how much of each? Here certainly one cannot be dogmatic. The same considerations which once gave all of Western Europe, England included, a single law merchant (and which now find expression in the European Common Market) suggest that Swift v. Tyson may have been right about questions of "mercantile law," its actual holding dealing as it did with the law of bills of exchange. Again, even though legislation on court "procedure in Civil Matters" is for the provinces, it would seem that the superintendence of actions of federal agencies and officials by prerogative writs or otherwise could well follow one uniform rule, to be prescribed by the Supreme Court.

The precise dividing line would need to be delineated, which, since there is no doubt about its constitutional power in the field, would remain a task for the Supreme Court. As a first approximation, however, it is submitted that the allocation of legislative powers between the two level of government expressed in the British North America Act, as it is or as it may become by amendment, indicates an agreement on what matters are of provincial and what of federal interest that might guide decision. Specifically, property and civil rights (as well as the application of provincial statutes generally) would be relinquished to provincial determination, which would, by and large, mean that each province would have the final voice as to the content of its common law or civil law.

Unlike most current proposals for remedying our national woes, this one requires no constitutional amendments and, indeed, none in the statutes, although some changes of the latter sort might remove unnecessary clutter. The constitutional positon is obvious. If, as I believe has been demonstrated, the British North America Act leaves the matter at large, all that is called for is for those vested with a discretion, in practice the judges of the Supreme Court, to exercise that discretion appropriately. Potentially, Parliament's discretion, too, may be involved; and it may be that section 101 is construable as authorizing it to indicate to the Supreme Court (as contrasted with other possible federal courts) the areas where that Court is to make the law and those where it is to receive it as formulated by provincial courts. In any case, Parliament has not undertaken any such directive. It has confined itself to stating in The Supreme Court Act what may be appealed, saying nothing about how appeals are to be determined. It may well be that, by rendering pointless those appeals involving only common law or civil law questions, the proposal would eliminate the occasion for some appeals which now come up under the amount-in-controversy authorization, ${ }^{1+}$ and thus would re-enforce the independently existing reasons for exscinding that section of the Act; but that is just a matter of neatness of the statute book. The Supreme Court Act may, perhaps, vaguely assume a Supreme Court monitoring of provincial judicial activity, as contrasted with the British North America Act's utter neutrality; but, if there is any such suggestion, it is so muted as to leave the Court quite at liberty to determine the basis for dismissing appeals.

In electing not to revamp the judicially declared law of the provinces regarding property and civil rights or other matters falling within their legislative competence, the Court would simply be extending to one more

11 The Supreme Court Act, R.S.C. 1952, c. 259, s.36, as amended by (Can.) 1956, c. 48, s.2. 
class of components of decision a self-denying policy familiar in other contexts. It is well-established that on matters of practice and procedure it will not entertain appeals and will certainly not revise the law as declared by the highest courts of the provinces. Again, it has refused to go behind concurrent fact evaluations by successive provincial courts at trial and on appeal. All that is needed to effectuate a programme of making the provinces judicially maitres chez soi is a comparable exercise of its discretion by the Court.

It seems likely that, aside from its contribution to the structure of Dominion-Provincial relations, there would be collateral benefits to the Court itself. The reduction in work load would contribute to allowing participation by the full bench in all cases, thus reducing the inherent uncertainties as to the predictive force of divisional decisions and, what is perhaps most important, bringing to each case the collective deliberation and wisdom of all the judges. Moreover, concentration on questions of federal law, as to which there is typically a wider public sensitiveness, might will enhance the status of the Court in our governmental system. While it already has the passive respect, it does not have the active interest of the nation, and serves less effectively than it might as a symbol of common Canadian purpose. By narrowing the range of its concerns, it could very well be that it would widen its institutional effectiveness.

Although these benefits are not negligible, they are secondary; the primary advantage is the greater responsiveness of the law to the differing needs and sentiments of the provinces. The geography or the sociology of British Columbia and of Nova Scotia are not, for example, so featureless that it is inadmissible for those communities to regard differently the position of one hazarding himself to the driving of a drunken companion. ${ }^{15}$ Family cohesiveness, the sophistication of bargainers, the incidence of urbanism, patterns of informal communication-these are some of the many circumstantial elements relevant to a different, but equally valid, development within the general framework of the common law amongst the provinces. One gets a feel for these matters only by living in a community. No amount of learning or intellectual acuity is quite a substitute. As was recognized before, there is a question of reconciling with other competing values this component of special local familiarity, ultimately for the deliberated determination of the Supreme Court itself under our constitution and statutes, but for which it was suggested that the division of legislative authority yields a useful first approximation to an answer. It is nihil ad rem to ask why one should not leave it to the legislatures to introduce diversity where a judicial doctrine is thought to be poorly adapted to provincial circumstances. Granted this can be done (although it is unrealistic to ignore the low priority which private law reform generally has on legislative agendas), the question-why not leave it to the legislatures to introduce uniformity where case law variations are not desired-is just as legitimate intrinsically; and, besides, is in conformity with the spirit of section 97.

Federalism is union without uniformity. Matters of common concern and the law about them are for the common government. Matters of

15 Compare Miller v. Decker, [1955] 4 D.L.R. 92, 13 W.W.R.(N.S.) 642 (B.C.C.A.) with Seymour v. Maloney, [1955] 4 D.L.R. 104, 36 M.P.R. 337 (N.S.C.A.) aff'd [1956] S.C.R. 322, 2 D.L.R. (2d) 369 . 
particular concern and the law about them are for the particular governments. Fundamentally, even if perhaps imperfectly, those notions pervade the Canadian constitutional structure as for the law emanating from the legislatures. But, for one who accepts the federal principle as valid and vital, it is equally true whoever makes the law and whatever form it takes. For him, the values of pluralism transcend the modes of expression; and federalsim which excludes its judicial aspect is perforce a hobbled federalism. 